\title{
Structural Elucidation Studies on 14- and 16-Membered Macrolide Aglycones by Accurate-Mass Electrospray Sequential Mass Spectrometry
}

\author{
Marc Roddis, Paul Gates, Ylva Roddis, ${ }^{*}$ and James Staunton \\ Department of Chemistry, University of Cambridge, Cambridge, United Kingdom
}

\begin{abstract}
Collision induced dissociation sequential mass spectrometry was used to investigate the fragmentation of the heptaketide macrolide aglycones, 6-deoxyerythronolide B (6-dEB), erythronolide B (EB), and acetate-starter EB (Ac-EB). The fragmentations of two previously reported octaketide analogs produced by "stuttering" of the erythromycin polyketide synthase, stuttered-6-dEB and acetate-starter stuttered-6-dEB were also studied. The accuracy with which the mass of each fragment was measured allowed it to be attributed to an unambiguous formula. Most of the experiments were repeated using samples dissolved in deuterated solvents. These data were then used to deduce plausible fragmentation pathways of the five compounds which were shown to have a high degree of similarity. Preliminary fragmentation analysis of a novel octaketide analog was performed and the structure was predicted as stuttered EB. Subsequent scale-up of the bacterial fermentations, followed by isolation and characterization by nuclear magnetic resonance spectroscopy confirmed this prediction. Further fragmentation experiments were then performed on this compound, which provided further evidence of the similarity of the fragmentation schemes. These results demonstrate the utility of collision induced dissociation sequential mass spectrometry analysis in the preliminary screening of bacterial fermentations for new polyketides. These studies were performed by electrospray ionization Fourier transform ion cyclotron resonance mass spectrometry. (J Am Soc Mass Spectrom 2002, 13, 862-874) (C 2002 American Society for Mass Spectrometry
\end{abstract}

$\mathrm{M}$ acrolide (macrocyclic lactone) antibiotics are a class of reduced polyketide natural products produced by various species of Streptomyces bacteria. They are biosynthesized on large, multifunctional, Type I polyketide synthase (PKS) enzymes by a series of repeated condensation steps, each serving to extend the growing chain by two carbon atoms in a process analogous to fatty acid biosynthesis [1].

The PKS contains a number of individual modules each of which catalyzes a single chain extension followed by various degrees of keto reduction. The modules also control stereochemistry and substrate specificity so that a variety of substructures may be encountered within a single polyketide molecule. The number of modules determines the overall chain length and a terminal thioesterase function finally catalyzes macrocyclic lactonization. The polyketide is then usually modified by a series of "tailoring" enzymes which

Published online May 29, 2002

Address reprint requests to Dr. P. J. Gates, Department of Chemistry, University of Cambridge, Lensfield Road, Cambridge CB21EW, UK. E-mail: pjg1002@cam.ac.uk

${ }^{*}$ Current address: KaroBio AB, Novum SE-141 57 Huddinge, Sweden. catalyze reactions such as methylation, hydroxylation and glycosylation. The biosynthesis of erythromycin A occurs in Saccharopolyspora erythraea and has been most extensively studied. Although the polyketide products are biosynthesized as single stereoisomers, no stereochemistry is depicted for any of the structures presented here because no information about stereochemistry could be deduced from the fragmentation experiments.

Erythromycin biosynthesis can be considered to occur in two stages; PKS-catalyzed formation of the first enzyme-free intermediate 6-deoxyerythronolide B (6$\mathrm{dEB}$ ) (Structure 1, Scheme 2) followed by post-PKS modification to produce erythromycin A (Scheme 1). The first post-PKS step involves the hydroxylation of 6-dEB to produce erythronolide B (EB) (Structure 2, Scheme 2). 6-dEB and EB are referred to as aglycones because they do not contain either of the sugar moieties present in erythromycin A. Although the post-PKS steps are required to produce active antibiotics, most academic research activity has focused upon the operations of the PKS. This is because the structure of the PKS products are programmed specifically in the genes encoding the PKS enzymes, allowing the biosynthetic 


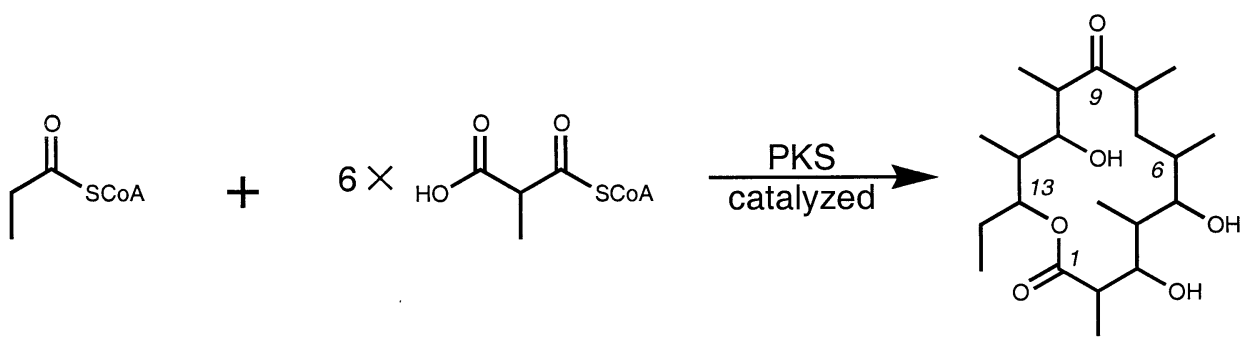

1: 6-dEB

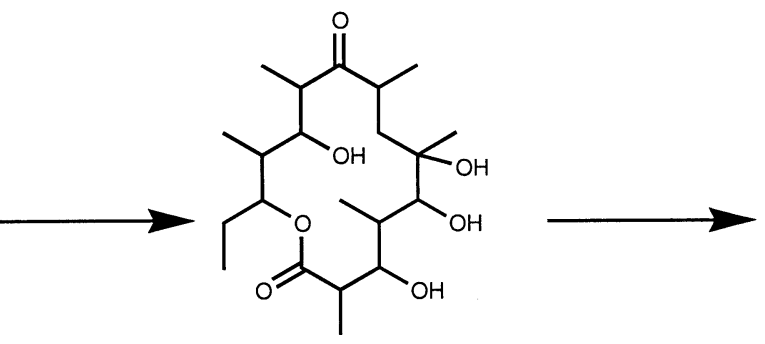

2: EB

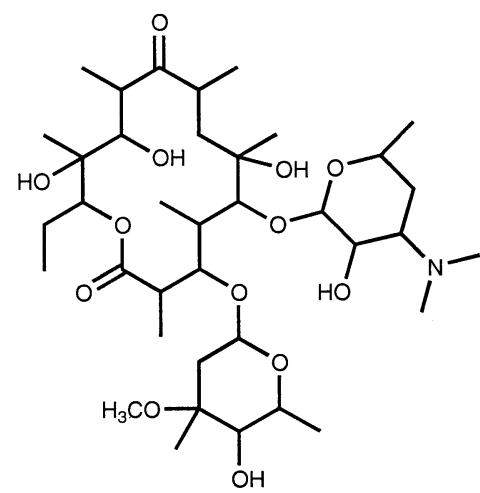

Erythromycin A

Scheme 1. An overview of the biosynthesis of erythromycin A.

process to be manipulated at the genetic level to produce specific structural modifications [1-4]. Particular interest is focused upon producing polyketide libraries through combinatorial genetic manipulation. To avoid producing an unmanageable number of compounds, such libraries are often limited to aglycones [5] which also have simpler structures and are thus easier to analyze.

Full characterization of the polyketide products requires the growth of large quantities of bacterial culture and purification of milligram quantities of analyte from a complex mixture, followed by analysis by nuclear magnetic resonance (NMR) spectroscopy. The large number of samples that may be expected from combinatorial experiments will require a faster, more sensitive analysis for preliminary screening and structure determination [5-7]. A more rapid method of molecular characterization may be high performance liquid chromatography (HPLC) followed by tandem (MS-MS) or sequential mass spectrometry $\left(\mathrm{MS}^{\mathrm{n}}\right)$, but for this to be of use some understanding of the fragmentation reactions of macrolide antibiotics is required.

This paper reports the first detailed fragmentation analysis of the macrolide aglycone biosynthetic intermediates towards erythromycin A-6-dEB and EB (for analysis of polyketide macrolides by mass spectrometry also see $[8 \mathrm{a}, \mathrm{b}, \mathrm{c}, \mathrm{d}, \mathrm{e}])$. These compounds incorporate a propionate starter acid during their biosynthesis that appears as an ethyl substituent at position 13 on the macrolide ring. The starter acid derived unit in each structure described is circled in Scheme 2. The production of polyketide analogs with different starter acids has been pursued by genetic manipulation and precursor-directed biosynthesis $[9,10]$. Structural modification at this site has yielded a greater number of analogs than at any other site on the macrolide ring. We therefore also performed fragmentation analysis on acetate starter EB (Ac-EB) (Structure 3), to investigate whether fragments containing the starter acid could be pinpointed on the fragmentation pathway. Previous MS-MS studies [11, 12] had achieved this using erythromycin A analogs with different starter acids incorporated.

We then focused upon performing a similar analysis on a pair of 16-membered macrolide aglycones containing acetate and propionate starters units. These compounds are produced by the aberrant function of the erythromycin PKS [13] and are identical to 6-dEB except that a 3-carbon unit, (boxed in Scheme 2) has been incorporated twice. This phenomenon has been referred to as "stuttering" [13] and consequently, these compounds are referred to as stuttered 6-dEB (stutt-6-dEB) (Structure 4) and acetate starter stuttered 6-dEB (Acstutt-6-dEB) (Structure 6) and to the 3-carbon unit as the "stuttered unit". The study of these compounds was important because they have been fully characterized by 2-D NMR spectroscopy and thus provided further solid evidence upon which to predict the structure of a 

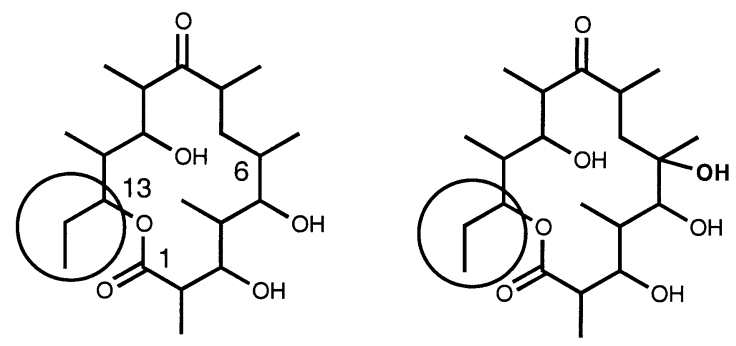

1: 6-dEB

2: EB<smiles>CC(C)OC(=O)C(C)C(O)C(C)C(O)C(C)(O)CC(C)C(C)C(=O)C(C)C</smiles>

3: Ac-EB

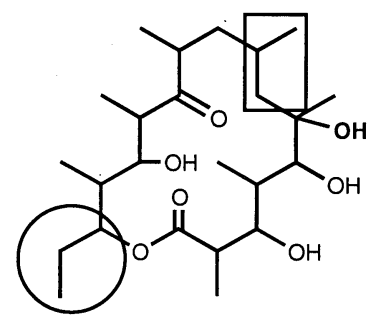

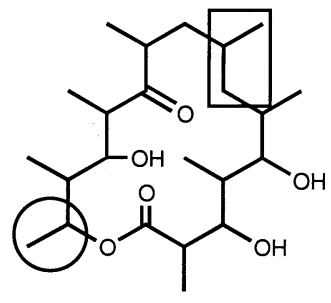

\section{5: Stutt-EB}

\section{6: Ac-stutt-6-dEB}

Scheme 2. The structures of the six compounds analyzed in this study. The structures differ in the nature of the starter units (circled) and the presence or absence of the "stuttered" units (boxed) and the C-6 hydroxyl (bold).

novel 16-membered macrolide aglycone as stutt-EB (Structure 5). This structure was later confirmed by scale-up of the bacterial fermentations, isolation by repeated preparative HPLC, and extensive NMR spectroscopy.

\section{Experimental}

\section{Materials}

6-dEB, EB, and Ac-EB were isolated (purity $\geq 98 \%$ ) from fermentations of genetically engineered bacteria by preparative HPLC. Details of the genetic engineering, product isolation, and characterization and of the insight obtained into the operation of the biosynthetic pathway are described elsewhere. The isolation of stutt6-dEB and Ac-stutt-6-dEB has been described [13]. GlaxoSmithKline kindly provided approximately 200 $\mathrm{mg}$ of each of these two products (purity $85 \%$ ) for use in the experiments reported. Initial experiments were performed on a $200 \mu \mathrm{g}$ sample of stutt-EB (purity $90 \%$ ) and then further experiments were performed on a $400 \mu \mathrm{g}$ sample (purity $\geq 98 \%$ ).

\section{Instrumentation}

All experiments were performed on a BioApex II (4.7 tesla) Fourier transform ion cyclotron resonance (FTICR) mass spectrometer (Bruker Daltonics, Billerica, MA) equipped with a standard electrospray ionization (ESI) source (Analytica of Branford, Branford, CT). Samples were stored neatly and dissolved in methanol/ water prior to running the experiments. Concentrations were approximately $50 \mu \mathrm{g} / \mathrm{ml}$ for the stuttered compounds, rising to $0.5 \mathrm{mg} / \mathrm{ml}$ for EB and 6-dEB. A methanol/water ratio of 50/50 gave the greatest signal stability. Satisfactory results could be obtained, however, with methanol proportions up to $75 \%$; this higher methanol content was required to dissolve the less polar octaketide macrolides in high enough concentration to obtain satisfactory signal-to-noise in the $\mathrm{MS}^{3}$ experiments. The solutions were infused into the ESI source at 80 to $120 \mu \mathrm{l} / \mathrm{h}$ from a syringe pump (74900 series, Cole Parmer Instrument Company, Vernon Hills, IL). High resolution MS-MS and $\mathrm{MS}^{3}$ analyses were performed by sustained off-resonance irradiation collision induced dissociation (SORI-CID) using $\mathrm{CO}_{2}$ collision gas. The parent ion for each experiment was selectively isolated through the use of correlated sweep isolation [14]. The cell conditions were tuned to fragment at least $50 \%$ of the parent ion. Precursor ions for multistage MS were optimized from the previous MS step before being isolated. Some MS-MS and MS $^{3}$ analyses were also performed in deuterated media $\left(\mathrm{CD}_{3} \mathrm{OD} / \mathrm{D}_{2} \mathrm{O}, 50-75 / 50-25 \%\right)$. All of the exchangeable protons were exchanged for deuterium with a consequent shift in mass to the deuterated pseudomolecular ion.

Accurate masses, within $5 \mathrm{ppm}$, were achieved for all of the fragment ions by the post-analysis application of a calibration obtained from a product ion spectrum of erythromycin A [11]. Formula assignment of unknown fragment ions was achieved by using the formula of the parent ion as the atom constraints for $\mathrm{C}, \mathrm{H}$, and $\mathrm{O}$. This usually only produced one possible match to within 50 $\mathrm{ppm}$. Where more than one possible match was produced, logical deductions about possible structures were made to eliminate the extraneous formulas.

\section{Results and Discussion}

\section{General Considerations}

Several assumptions were used to facilitate the analysis presented below. First, we have assumed that the number of atoms of each element in the daughter ions in each spectrum is not greater than that in the precur- 


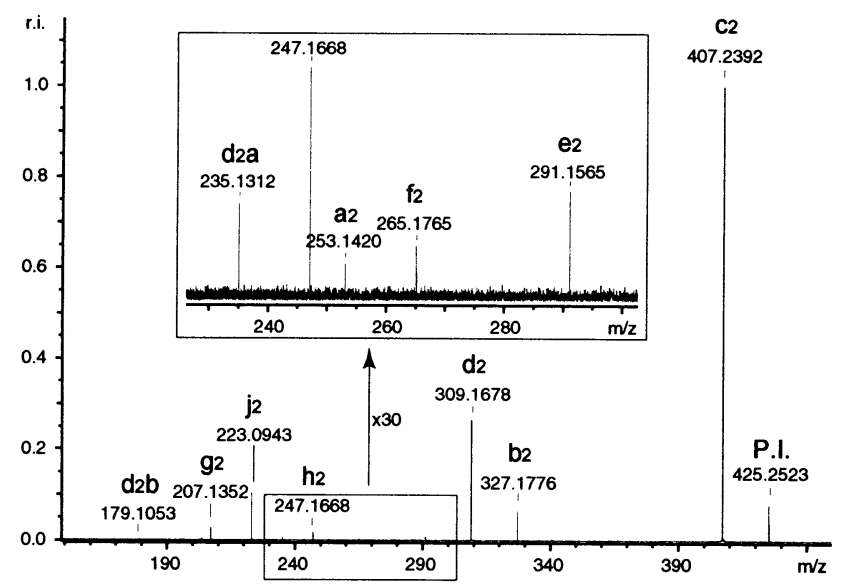

Figure 1. The ESI-FTICR MS-MS product ion spectrum of EB: Precursor ion $m / z 425$.

sor ion. Thus for almost every fragment ion observed in this study the observed mass matched to only a single molecular formula within $50 \mathrm{ppm}$. The mass error (difference between observed mass and calculated mass for that formula) was within $5 \mathrm{ppm}$. Second, in the MS-MS and $\mathrm{MS}^{3}$ analyses we have inferred that daughter ions present might have arisen from two or more sequential fragmentations. For example, some spectra show peaks for the losses of $\mathrm{CO}_{2}, \mathrm{H}_{2} \mathrm{O}$, and $\mathrm{CH}_{2} \mathrm{O}_{3}$. In such cases, we have inferred that the latter loss occurs by the stepwise losses of $\mathrm{CO}_{2}$ and $\mathrm{H}_{2} \mathrm{O}$ rather than the direct loss of a $\mathrm{CH}_{2} \mathrm{O}_{3}$ unit, because such a unit is not present in the structures analyzed. Therefore, we have made a judgement when drawing each fragmentation scheme, from which parent ion(s) a daughter ion might originate. This has been done because it was not possible to obtain a complete set of $\mathrm{MS}^{3}$ data in all cases and the fragmentation pathways given are simply the best representation we can provide based upon all the data obtained. However, the schemes do provide a consistent illustration of the $\mathrm{C}-\mathrm{C}$ bonds that are broken in each fragmentation and exemplify the analogies between the fragmentation pathways of each compound. The fact that in many cases several isomeric ions are probably present is illustrated by spectra of samples dissolved in deuterated solvents in which clusters of ions, each having high intensity and a different number of deuterium atoms in place of hydrogens, are observed.

In all cases, sodiated ions were chosen as precursor ions for fragmentation. Under normal solvent and $\mathrm{pH}$ conditions, the macrolide aglycones do not produce (a)

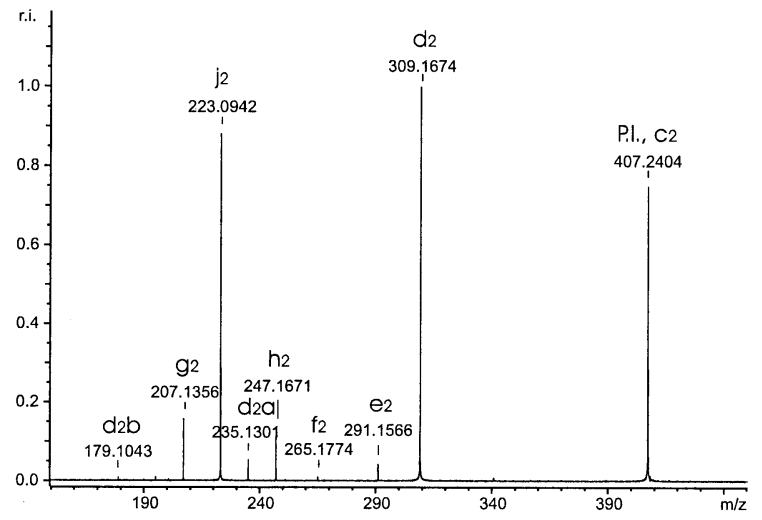

(c)

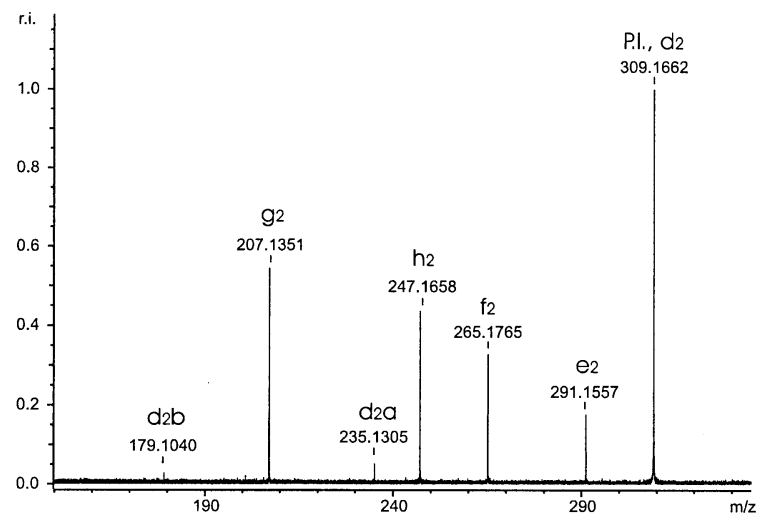

(b)

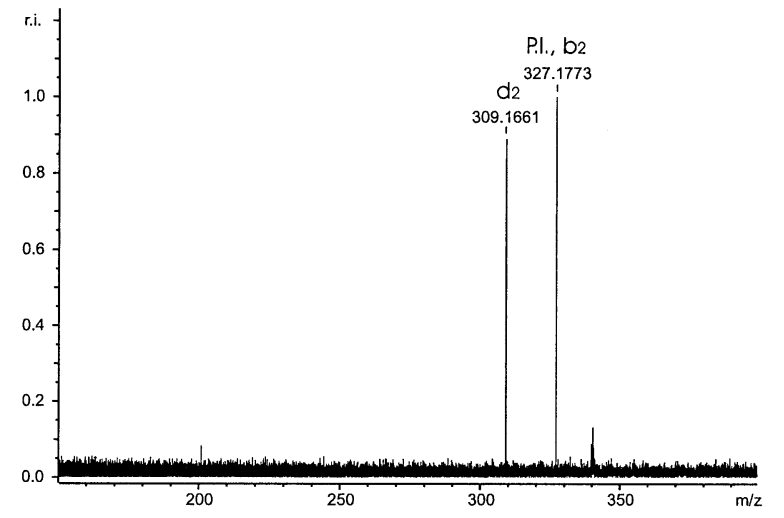

(d)

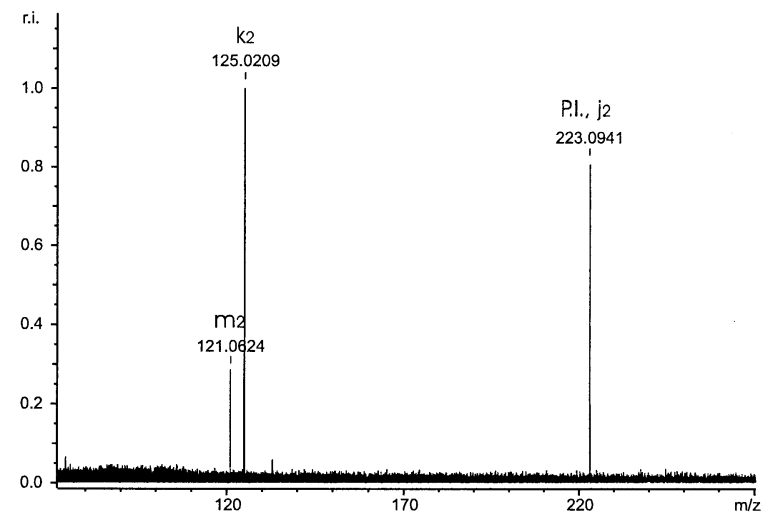

Figure 2. The ESI-FTICR MS ${ }^{3}$ product ion spectra of EB: Precursor ions (a) $m / z ~ 407$, (b) $\mathrm{m} / \mathrm{z} 327$, (c) $\mathrm{m} / \mathrm{z} 309$, and (d) $\mathrm{m} / \mathrm{z} 223$. All the precursor ions were optimized and isolated from the MS-MS analysis (Figure 1). 


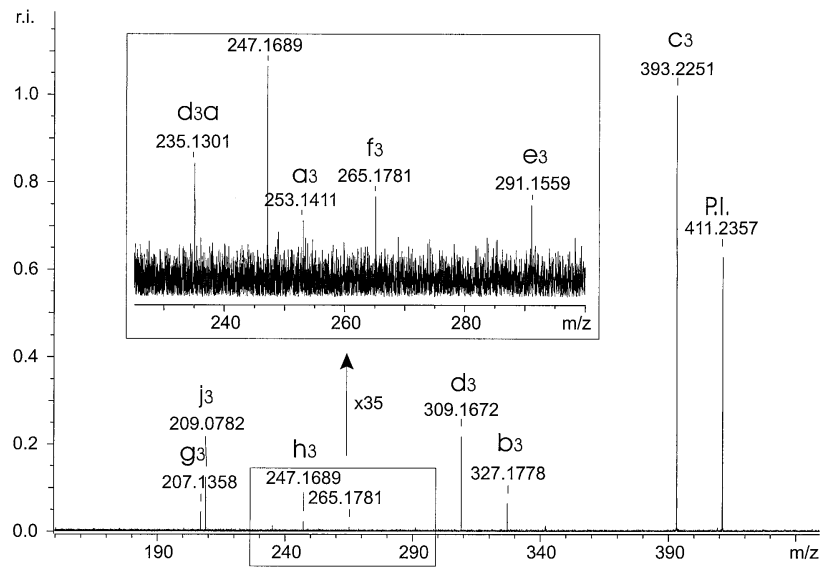

Figure 3. The ESI-FTICR MS-MS product ion spectrum of Ac-EB: precursor ion $m / z 411$.

protonated ions. The previous studies performed by this group on the fully processed polyketides [11, 12] (i.e., those containing the sugar moieties) show that although these do produce abundant protonated ions, fragmentation of the sodiated ions produce more structural information from less $\mathrm{MS}^{\mathrm{n}}$ steps.

In producing the fragmentation schemes we have attempted to put forward the simplest explanation consistent with all the data. We have tried to explain fragmentations using mechanisms that are known to be commonly observed when using CID and ESI, for example retro-aldol fragmentations, and to avoid invoking rearrangements, bimolecular reactions, homolytic bond fissions, and what we consider to be other ostensibly high-energy pathways. Each fragmentation reaction results in two fragments, one of which retains the charge and the other is lost as a neutral molecule. In some cases the charge can be retained by either fragment, producing two fragmentation routes from the same parent ion. We have also tried to use a consistent nomenclature for identifying the fragment ions. All ions are labeled $x_{n}$ where $x$ identifies the fragment ion and $n$ identifies the analyte. For example: Ions $\mathbf{a}_{\mathbf{1}}$ and $\mathbf{a}_{\mathbf{2}}$ are the result of the same fragment mechanism for analytes 1 and 2, whereas ions $\mathbf{a}_{\mathbf{1}}$ and $\mathbf{b}_{\mathbf{1}}$ are the result of different mechanism for the same analyte.

\section{Erythronolide B (EB) and Acetate Starter EB (Ac-EB)}

The MS-MS analysis of the $[\mathrm{M}+\mathrm{Na}]^{+}$ion of EB $(\mathrm{m} / \mathrm{z}$ 425 ) is shown in Figure 1. The MS ${ }^{3}$ analyses of $m / z$ 407, 327,309 , and 223 isolated from the MS-MS analysis were also recorded (Figure 2). The five corresponding spectra were obtained from EB dissolved in deuterated media. Most of the corresponding ions were observed; the failure to observe some of the ions can be attributed to the lower concentration of EB used in the deuterated media. Two experiments were run on Ac-EB; the MS-MS of the $[\mathrm{M}+\mathrm{Na}]^{+}$ion $(\mathrm{m} / z$ 411) (shown in Figure 3 ) and the $\mathrm{MS}^{3}$ of the $m / z 209$ fragment ion. The MS-MS analysis of Ac-EB resulted in fragment ions at $\mathrm{m} / \mathrm{z} 393$, $327,309,291,265,253,247,235,209$, and 207 and the MS $^{3}$ of $m / z 209$ resulted in ions at $m / z 125$ and 107. The results from all of the experiments on EB are summarized in Table 1, and experiments on Ac-EB in Table 2.

Three ions $(\mathrm{m} / \mathrm{z} 407,327$, and 253) in the MS-MS analysis of sodiated EB $(\mathrm{m} / \mathrm{z} 425)$ do not appear in any of the recorded $\mathrm{MS}^{3}$ spectra. Clearly $\mathrm{m} / \mathrm{z} 407$ and 327 are direct fragmentations from 425 , corresponding to the loss of $\mathrm{H}_{2} \mathrm{O}$ and $\mathrm{C}_{6} \mathrm{H}_{10} \mathrm{O}$, respectively. The $\mathrm{m} / \mathrm{z} 253$ fragment results from a loss of $\mathrm{C}_{9} \mathrm{H}_{16} \mathrm{O}_{3}$ from $\mathrm{m} / z 425$ and can be regarded as occurring directly from the parent ion. This fragmentation could arise by cleavage of various pairs of bonds, for example, A and B, C and

Table 1. The formula, fragment ion identity, theoretical calculated mass, and mass measurement error (ppm) for every ion observed in the MS-MS and MS ${ }^{3}$ experiments on EB (see Figures 1 and 2)

\begin{tabular}{|c|c|c|c|c|c|}
\hline Formula & $\begin{array}{c}\text { Fragment } \\
\text { identity }\end{array}$ & $\begin{array}{c}\text { Theoretical } \\
\text { mass }\end{array}$ & $\begin{array}{l}\text { Mass error } \\
(\mathrm{ppm})\end{array}$ & $\begin{array}{l}\text { Number of } \\
\text { deuteriums }\end{array}$ & $\begin{array}{c}\text { Ratio of } \\
\text { deuteriums }\end{array}$ \\
\hline $\mathrm{C}_{21} \mathrm{H}_{38} \mathrm{O}_{7} \mathrm{Na}^{+}$ & P.I. & 425.25097 & +3.25 & 4 & \\
\hline $\mathrm{C}_{21} \mathrm{H}_{36} \mathrm{O}_{6} \mathrm{Na}^{+}$ & $\mathrm{c}_{2}$ & 407.24041 & -3.07 & $2,3^{b}$ & $91: 9$ \\
\hline $\mathrm{C}_{15} \mathrm{H}_{28} \mathrm{O}_{6} \mathrm{Na}^{+}$ & $b_{2}$ & 327.17781 & -0.64 & 4 & \\
\hline $\mathrm{C}_{15} \mathrm{H}_{26} \mathrm{O}_{5} \mathrm{Na}^{+}$ & $d_{2}$ & 309.16724 & +1.91 & 2,3 & $69: 31$ \\
\hline $\mathrm{C}_{15} \mathrm{H}_{24} \mathrm{O}_{4} \mathrm{Na}^{+}$ & $\mathrm{e}_{2}$ & 291.15668 & -0.69 & 1,2 & $67: 33$ \\
\hline $\mathrm{C}_{14} \mathrm{H}_{26} \mathrm{O}_{3} \mathrm{Na}^{+}$ & $f_{2}$ & 265.17741 & -3.32 & 2,3 & $67: 33$ \\
\hline $\mathrm{C}_{12} \mathrm{H}_{22} \mathrm{O}_{4} \mathrm{Na}^{+}$ & $a_{2}$ & 253.14103 & +3.87 & 3 & \\
\hline $\mathrm{C}_{14} \mathrm{H}_{24} \mathrm{O}_{2} \mathrm{Na}^{+}$ & $\mathrm{h}_{2}$ & 247.16685 & -0.20 & 1,2 & $67: 33$ \\
\hline $\mathrm{C}_{12} \mathrm{H}_{20} \mathrm{O}_{3} \mathrm{Na}^{+}$ & $d_{2} a$ & 235.13046 & +3.32 & 1 & \\
\hline $\mathrm{C}_{10} \mathrm{H}_{16} \mathrm{O}_{4} \mathrm{Na}^{+}$ & $\mathrm{j}_{2}$ & 223.09408 & +1.12 & 0 & \\
\hline $\mathrm{C}_{11} \mathrm{H}_{20} \mathrm{O}_{2} \mathrm{Na}^{+}$ & $g_{2}$ & 207.13555 & -1.59 & 1,2 & $39: 61$ \\
\hline $\mathrm{C}_{9} \mathrm{C}_{16} \mathrm{O}_{2} \mathrm{Na}^{+}$ & $d_{2} b$ & 179.10425 & +0.34 & & \\
\hline $\mathrm{C}_{4} \mathrm{C}_{6} \mathrm{O}_{3} \mathrm{Na}^{+}$ & $\mathrm{k}_{2}$ & 125.02091 & 0.00 & 0 & \\
\hline $\mathrm{C}_{6} \mathrm{H}_{10} \mathrm{ONa}^{+}$ & $\mathrm{m}_{2}$ & 121.06239 & 0.00 & 0 & \\
\hline Average difference (rms) & & & 1.67 & & \\
\hline (mean residual) & & & +0.31 & & \\
\hline
\end{tabular}

${ }^{a}$ For each of the ions observed in the experiments performed using deuterated media, the number of deuteriums present is given. ${ }^{b}$ For species that have different masses only by virtue of the number of deuteriums they contain, the relative intensities are also given. 
Table 2. The formula, fragment ion identity, theoretical calculated mass, and mass measurement error (ppm) for every ion observed in the MS-MS and MS ${ }^{3}$ experiments on AcEB (see Figure 3)

\begin{tabular}{lccr}
\hline Formula & $\begin{array}{c}\text { Fragment } \\
\text { identity }\end{array}$ & $\begin{array}{c}\text { Theoretical } \\
\text { mass }\end{array}$ & $\begin{array}{c}\text { Mass Error } \\
\text { (ppm) }\end{array}$ \\
\hline \hline $\mathrm{C}_{20} \mathrm{H}_{36} \mathrm{O}_{7} \mathrm{Na}^{+}$ & $\mathrm{P} . \mathrm{I}$. & 411.23532 & +1.02 \\
$\mathrm{C}_{20} \mathrm{H}_{34} \mathrm{O}_{6} \mathrm{Na}^{+}$ & $\mathrm{C}_{3}$ & 393.22476 & +0.97 \\
$\mathrm{C}_{15} \mathrm{H}_{28} \mathrm{O}_{6} \mathrm{Na}^{+}$ & $\mathrm{b}_{3}$ & 327.17781 & 0.00 \\
$\mathrm{C}_{15} \mathrm{H}_{26} \mathrm{O}_{5} \mathrm{Na}^{+}$ & $\mathrm{d}_{3}$ & 309.16724 & -0.06 \\
$\mathrm{C}_{15} \mathrm{H}_{24} \mathrm{O}_{4} \mathrm{Na}^{+}$ & $\mathrm{e}_{3}$ & 291.15668 & -2.71 \\
$\mathrm{C}_{14} \mathrm{H}_{26} \mathrm{O}_{3} \mathrm{Na}^{+}$ & $\mathrm{f}_{3}$ & 265.17741 & +2.75 \\
$\mathrm{C}_{12} \mathrm{H}_{22} \mathrm{O}_{4} \mathrm{Na}^{+}$ & $\mathrm{a}_{3}$ & 253.14103 & +0.40 \\
$\mathrm{C}_{14} \mathrm{H}_{24} \mathrm{O}_{2} \mathrm{Na}^{+}$ & $\mathrm{h}_{3}$ & 247.16685 & +0.16 \\
$\mathrm{C}_{12} \mathrm{H}_{20} \mathrm{O}_{3} \mathrm{Na}^{+}$ & $\mathrm{d}_{3} \mathrm{a}$ & 235.13046 & -1.53 \\
$\mathrm{C}_{9} \mathrm{H}_{14} \mathrm{O}_{4} \mathrm{Na}^{+}$ & $\mathrm{j}_{3}$ & 209.07843 & -1.34 \\
$\mathrm{C}_{11} \mathrm{H}_{20} \mathrm{O}_{2} \mathrm{Na}^{+}$ & $\mathrm{g}_{3}$ & 207.13555 & +1.21 \\
$\mathrm{C}_{4} \mathrm{H}_{6} \mathrm{O}_{3} \mathrm{Na}^{+}$ & $\mathrm{k}_{3}$ & 125.02091 & -2.88 \\
$\mathrm{C}_{5} \mathrm{H}_{8} \mathrm{ONa}^{+}$ & $\mathrm{m}_{3}$ & 107.04674 & +4.30 \\
Average difference (rms) & & & 1.49 \\
(mean residual) & & & +0.19 \\
\hline
\end{tabular}

$\mathrm{D}, \mathrm{E}$ and $\mathrm{F}$, and $\mathrm{G}$ and $\mathrm{H}$ (see Scheme 3). The possibility of fragments of the same formula being produced in so many ways illustrates the high degree of symmetry exhibited by these molecules and consequently the difficulty of the fragmentation analysis. For this reason it was not possible to deduce the exact structures of some of the fragments. In particular the locations of the water losses cannot be deduced from the data and it is evident from the spectra of samples in deuterated media that losses of 18,19 , and 20 corresponding to $\mathrm{H}_{2} \mathrm{O}, \mathrm{HOD}$, and $\mathrm{D}_{2} \mathrm{O}$ can occur in parallel. Thus, many of the peaks observed represent a mixture of isomeric fragments (ignoring the isotopic labels). In fact, we were unable to explain reasonably the appearance of certain peaks in the fragmentation analysis of 6-dEB without invoking the presence of isomeric fragments (see
Scheme 8). However, for most of the non-water losses observed for each of the analogs it was possible to attribute the lost fragment to having originated from a specific region of the parent ion. For example, for the $\mathrm{C}_{9} \mathrm{H}_{16} \mathrm{O}_{3}$ loss, a fragment of the same formula $\left(\mathrm{C}_{8} \mathrm{H}_{14} \mathrm{O}_{3}\right.$ in the case of compounds containing an acetate starter) is lost either directly or stepwise for all of the compounds discussed. Therefore, it appears likely that the loss is from the same unit of the molecule in each case and that this unit contains the starter unit and does not contain the 6-OH or "stuttered" unit. Thus, a possible structure is presented in Scheme 4, which shows the fragmentation reactions that are observed for all of the analogs (the only exception was that fragment $\mathbf{b}_{4}$ was not observed in experiments on stutt-6-dEB). This scheme illustrates the high degree of similarity between the fragmentation pathways of all of the analogs.

The $\mathrm{MS}^{3}$ fragmentation of $\mathrm{m} / \mathrm{z} 327$ (Figure $2 \mathrm{~b}$ ) gave only one daughter ion, $\mathrm{m} / \mathrm{z} 309$, corresponding to the loss of $\mathrm{H}_{2} \mathrm{O}$. The largest fragment in the $\mathrm{MS}^{3}$ spectrum of $\mathrm{m} / \mathrm{z} 407$ (Figure 2c) has $\mathrm{m} / \mathrm{z} 309$, which also results from the loss of $\mathrm{C}_{6} \mathrm{H}_{10} \mathrm{O}$ (mass 98). The location of this loss can be pinpointed by comparison with the MS-MS analysis of sodiated Ac-EB m/z 411 (Figure 3) in which a fragment $\mathrm{m} / \mathrm{z} 327$ is also present resulting from the loss of $\mathrm{C}_{5} \mathrm{H}_{8} \mathrm{O}$ (mass 84). Considered together with the data for stutt-6-dEB and Ac-stutt-6-dEB presented here and in previous studies [11, 12], it is clear that the losses of mass 98 or 84 from the sodiated pseudomolecular ion or dehydrated sodiated pseudomolecular ion are diagnostic of the presence of a propionate or acetate starter, respectively. The loss of the $\mathrm{C}_{6} \mathrm{H}_{10} \mathrm{O}$ fragment was studied further using samples of EB, 6-dEB, and stutt-EB dissolved in deuterated media. The number of deuteriums remaining in the fragment ions did not decrease upon the loss of $\mathrm{C}_{6} \mathrm{H}_{10} \mathrm{O}$ from the pseudomolecular ion of each compound and from the $\mathrm{m} / \mathrm{z} 409$ ion

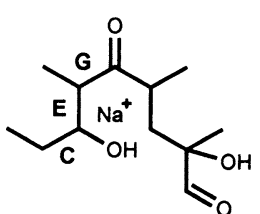

$A$ and $B$ broken

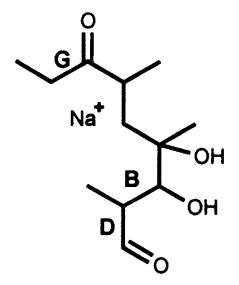

$E$ and $F$ broken

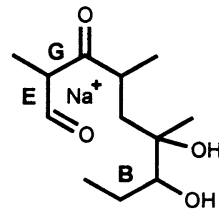

$\mathrm{C}$ and $\mathrm{D}$ broken

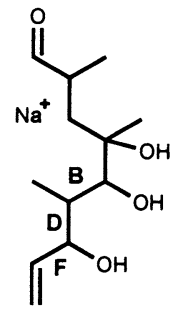

$\mathrm{G}$ and $\mathrm{H}$ broken

Scheme 3. Four alternative pairs of hypothetical bond cleavages that would each result in the formation of a fragment of formula $\mathrm{C}_{12} \mathrm{H}_{22} \mathrm{O}_{4} \mathrm{Na}^{+}$. This illustrates the high degree of symmetry in the structures analyzed. 
(a)
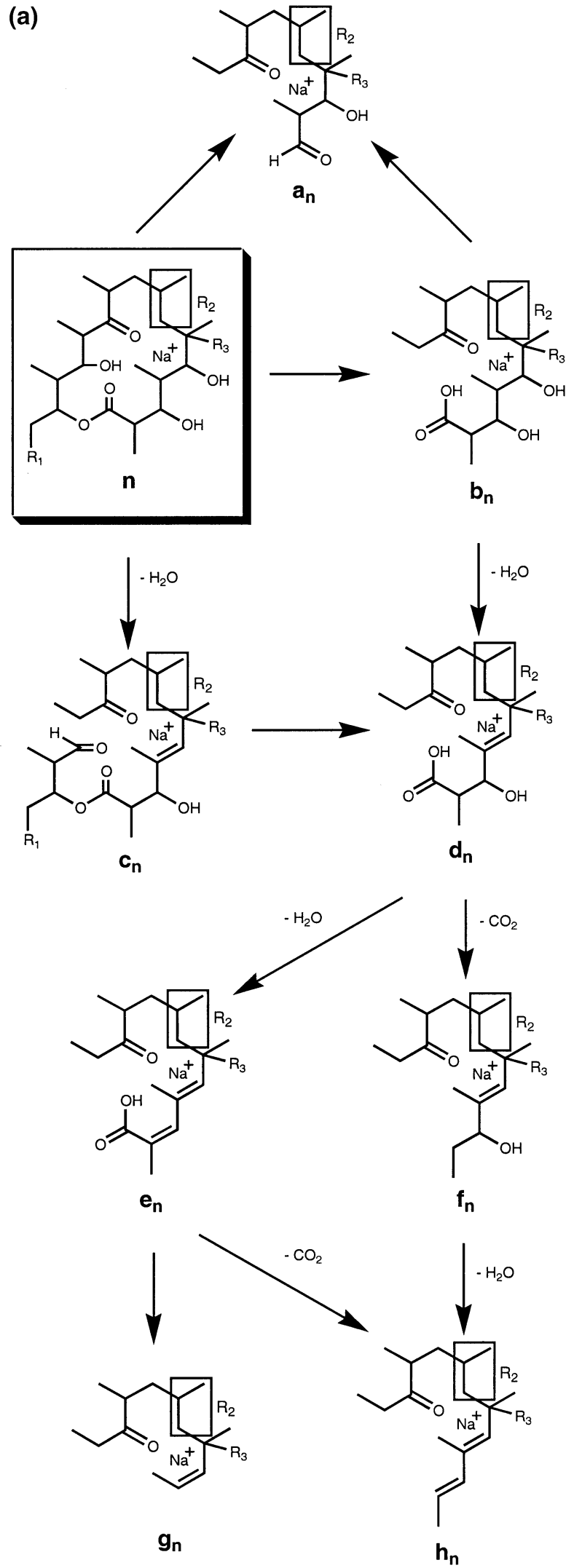

Scheme 4. (a) Proposed fragmentation scheme illustrating the common fragmentations observed for all of the analogs studied. The structures shown illustrate the regions of the ions from which the observed losses can be most reasonably by postulated to occur. The "stuttered" unit is shown boxed. (b) Key to Scheme 4a. (b)

\begin{tabular}{lcccc}
\hline Sample & $\begin{array}{c}\text { Structure } \\
\text { Identity }(\mathrm{n})\end{array}$ & $\mathrm{R}_{1}$ & $\mathrm{R}_{2}$ & $\mathrm{R}_{3}$ \\
\hline \hline 6-dEB & 1 & $\mathrm{Me}$ & not present & $\mathrm{H}$ \\
EB & 2 & $\mathrm{Me}$ & not present & $\mathrm{OH}$ \\
Ac-EB & 3 & $\mathrm{H}$ & not present & $\mathrm{OH}$ \\
stutt 6-dEB & 4 & $\mathrm{Me}$ & present & $\mathrm{H}$ \\
stutt EB & 5 & $\mathrm{Me}$ & present & $\mathrm{OH}$ \\
stutt Ac-6-dEB & 6 & $\mathrm{H}$ & present & $\mathrm{H}$ \\
\hline
\end{tabular}

isolated from the MS-MS analysis of EB. However, the corresponding fragment ion from 6-dEB, $\mathrm{m} / \mathrm{z} 393$, lost both $\mathrm{C}_{6} \mathrm{H}_{10} \mathrm{O}$ and $\mathrm{C}_{6} \mathrm{H}_{9} \mathrm{OD}$. Later correlations (see Scheme 8 and the associated text) indicated that these two losses occurred from different regions of the $\mathrm{m} / \mathrm{z}$ 391 ion. The region from which the $\mathrm{C}_{6} \mathrm{H}_{9} \mathrm{OD}$ loss is believed to occur is shown boxed on the penultimate structure of Scheme 5, which for clarity shows only a mechanism of $\mathrm{C}_{6} \mathrm{H}_{10} \mathrm{O}$ loss from the pseudomolecular ion of EB. However, all of the observations obtained from samples of 6-dEB, EB, and stutt-EB in deuterated solvents can be accounted for on the basis of this mechanism. This mechanism also illustrates the fact that the number of deuteriums retained does not necessarily tally with the number of "exchangeable" (i.e., heteroatom-bound) protons/deuterons in the structure. This is because deuterons can become incorporated in "non-exchangeable" positions in the structure and that under the fragmentation conditions deuteron exchange may not necessarily occur.

The only other fragment from the MS-MS of $m / z 425$ (Figure 1) that does not appear in any of the other $\mathrm{MS}^{3}$ spectra is $\mathrm{m} / \mathrm{z} 223$, corresponding to a loss of $\mathrm{C}_{11} \mathrm{H}_{20} \mathrm{O}_{2}$. MS $^{3}$ of $m / z 223$ (Figure 2d) gave two fragments, $m / z 125$ $\left(\mathrm{C}_{4} \mathrm{H}_{6} \mathrm{O}_{3} \mathrm{Na}^{+}\right)$and $\mathrm{m} / \mathrm{z} 121\left(\mathrm{C}_{6} \mathrm{H}_{10} \mathrm{ONa}^{+}\right)$. The MS-MS analysis of sodiated Ac-EB (Figure 3) has a fragment peak at $m / z 209$ and $\mathrm{MS}^{3}$ of this ion gives two fragments, $m / z 125\left(\mathrm{C}_{4} \mathrm{H}_{6} \mathrm{O}_{3} \mathrm{Na}^{+}\right)$and $\mathrm{m} / z 107\left(\mathrm{C}_{5} \mathrm{H}_{8} \mathrm{ONa}^{+}\right)$. Thus the $\mathrm{m} / \mathrm{z} 223$ and 121 from EB and $\mathrm{m} / \mathrm{z} 209$ and 107 from Ac-EB all contain the starter unit. Further evidence for the identity of the $\mathrm{m} / \mathrm{z} 223$ peak was obtained from the corresponding MS-MS and $\mathrm{MS}^{3}$ analyses performed in deuterated media. The $\mathrm{m} / \mathrm{z} 223$ fragment was unshifted in mass indicating that the all four of the deuterium atoms incorporated into EB had been lost during the formation of this fragment. The deuteriums originally exchanged onto the hydroxyl groups of C-3 and C-11 could both be lost in the formation of $\mathrm{m} / \mathrm{z} 223$ by mechanisms similar to that shown in Scheme 4. The absence of deuterium, the presence of the starter unit, and the molecular formula match of $\mathrm{m} / \mathrm{z} 223$ are consistent with the Structure $\mathbf{j}$ (see Scheme 6). Furthermore, the $m / z 125$ and 121 fragments $\mathbf{k}$ and $\mathbf{m}$ can be formed from 223 via a low-energy elimination of the acyloxy group, contain the starter unit as required, and have the correct formulas. The presence of both of these ions in the $\mathrm{MS}^{3}$ spectrum of $\mathrm{m} / \mathrm{z} 223$ is probably due to each being lost as either an ion or neutral molecule. The loss 


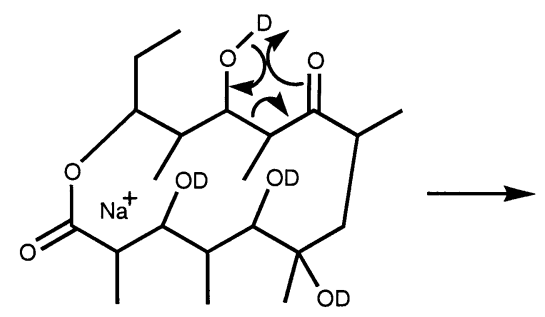

deuterated EB $m / z 429$

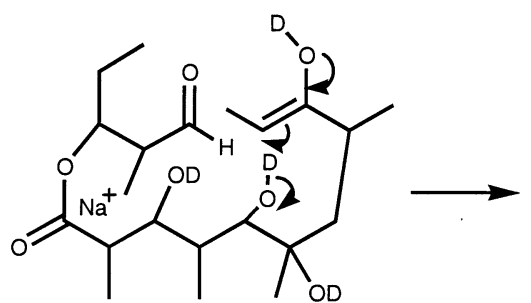

$m / z 429$

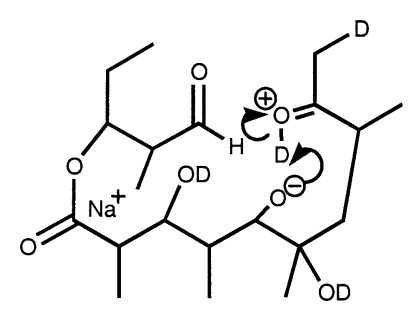

$m / z 429$

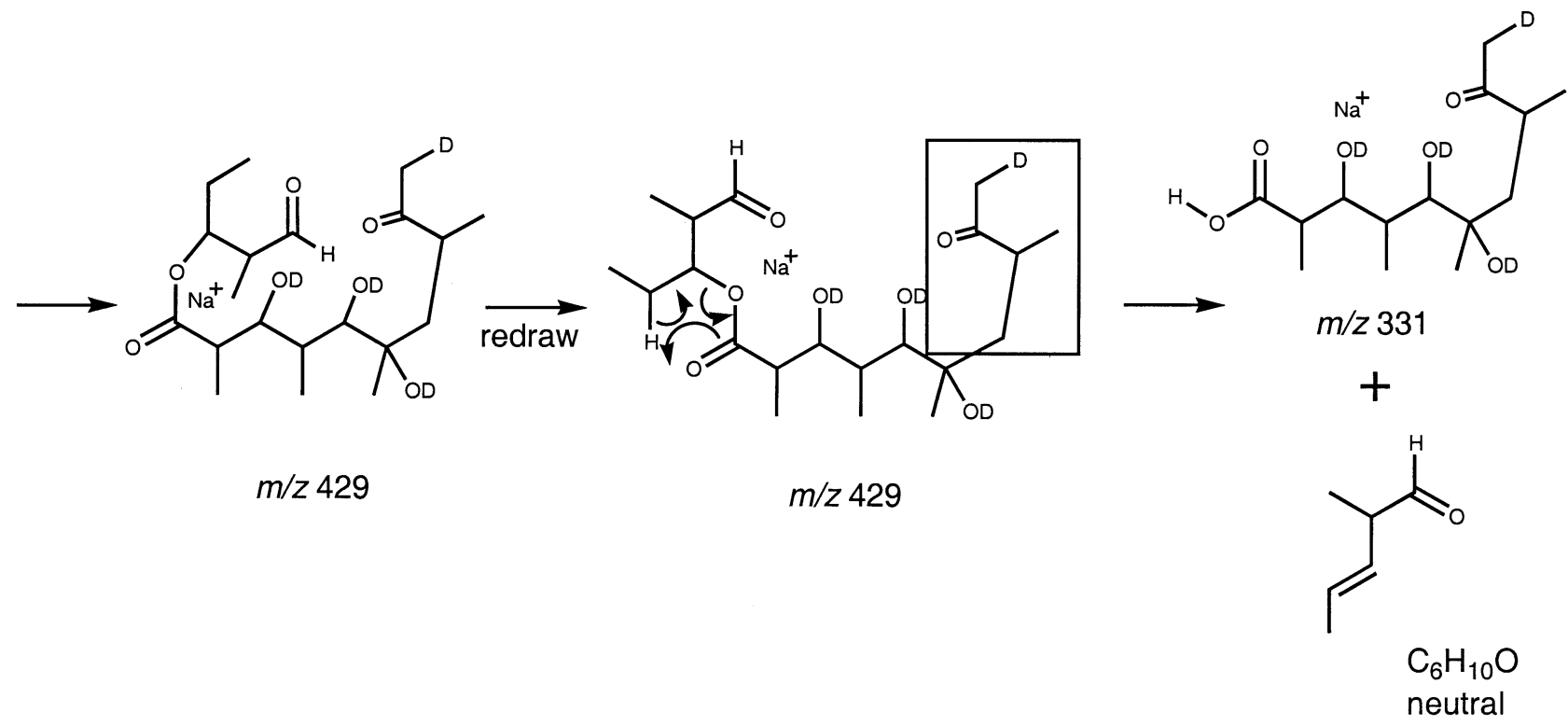

Scheme 5. A proposed mechanism for the loss of the starter-unit-containing fragment, which was observed for all of the analogs. For clarity only the loss from EB is shown. In the case of 6-dEB, loss of the boxed fragment would give the additional loss of $\mathrm{C}_{6} \mathrm{H}_{9} \mathrm{OD}$ as observed.

of $\mathrm{C}_{11} \mathrm{H}_{20} \mathrm{O}_{2}$ from the dehydrated pseudomolecular ion was also observed for stutt-EB and possibly 6-dEB (the $\mathrm{m} / \mathrm{z} 223$ in the $\mathrm{MS}^{3}$ spectrum of $\mathrm{m} / \mathrm{z} 391$ might arise directly, in addition to stepwise, from $\mathrm{m} / \mathrm{z} 293$ ), but the<smiles>CCCCCCCCCCCCCCCCC(=O)C(C)C(=O)O</smiles>

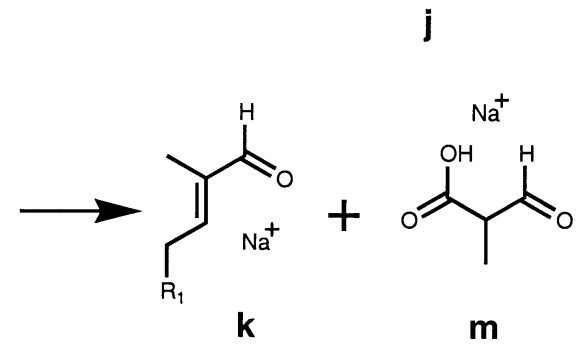

Scheme 6. Structures illustrating the regions of EB from which the $\mathrm{m} / \mathrm{z} 223(\mathbf{j}), 121(\mathbf{k})$ and $125(\mathbf{m})$ ions are proposed to originate. subsequent fragmentation of the resulting fragment was not.

The $\mathrm{MS}^{3}$ spectrum of $\mathrm{m} / \mathrm{z} 309$ (Figure 2c) showed six fragments, $m / z 291,265,247,235,207$, and 179 , none of which were observed in the MS $^{3}$ spectrum of $\mathrm{m} / \mathrm{z} 223$. Each of these fragments can be envisaged to arise directly from $\mathrm{m} / \mathrm{z} 309$ by relatively simple mechanisms. However, $m / z 247$ most likely arises by the loss of $\mathrm{H}_{2} \mathrm{O}$ from $\mathrm{m} / \mathrm{z} 265$ or of $\mathrm{CO}_{2}$ from $\mathrm{m} / \mathrm{z} 291$ rather than the direct loss of a $\mathrm{CH}_{2} \mathrm{O}_{3}$ unit. In the absence of extra $\mathrm{MS}^{3}$ fragmentation spectra it is not possible to be certain whether many of the fragments observed in the $\mathrm{MS}^{3}$ spectrum of $\mathrm{m} / \mathrm{z} 309$ were the result of single or sequential fragmentations. However, the formulas of these ions and the number of deuteriums they retain from the deuterated pseudomolecular ion provide some hints of the fragmentation sequence. For example, the ions corresponding to $\mathrm{m} / \mathrm{z} 309$ and 291 have formulas $\mathrm{CO}_{2}$ higher than $\mathrm{m} / \mathrm{z} 265$ and 249 and the same number of deuteriums so these latter ions can be attributed to arise by losses of $\mathrm{CO}_{2}$ from the respective former ions. Also, the $\mathrm{MS}^{3}$ spectrum of $\mathrm{m} / \mathrm{z} 311$ (equivalent to $\mathrm{m} / \mathrm{z} 309$ in non-deuterated experiments) from EB in deuterated 
medium shows the presence of one deuterium in the $\mathrm{m} / \mathrm{z} 291$ ion (i.e., a peak at $\mathrm{m} / \mathrm{z} 292$ ), but two deuteriums in some of the $m / z 247$ ions (i.e., a peak at $m / z 249$ ). Thus the possibility that all of the $\mathrm{m} / \mathrm{z} 247$ arises from $\mathrm{m} / \mathrm{z} 291$ by loss of $\mathrm{CO}_{2}$ can be effectively ruled out because such an event would require the concomitant gain of deuterium.

For each of the ions $m / z 309,291,265,247$, and 207 the observed masses matched the molecular formulas shown in Table 1. All of these ions also appear in the MS-MS analysis of Ac-EB (Figure 3) and match the same molecular formulas, so we deduce that none of them contain the starter unit. Also, in the MS-MS and MS ${ }^{3}$ analyses from 6-dEB, stutt-6-dEB, Ac stutt-6-dEB and stutt EB (Tables 4, 5, 6 and 7), the five corresponding fragment ions were observed, each matching molecular formula $\mathrm{O}$ lower, $\mathrm{C}_{3} \mathrm{H}_{6}$ higher, $\mathrm{C}_{2} \mathrm{H}_{4}$ higher and $\mathrm{C}_{3} \mathrm{H}_{6} \mathrm{O}$ higher than the corresponding $\mathrm{EB}$ fragments. These molecular formulas differences are identical to those between the macrolide aglycones used in the fragmentation analyses. Therefore, all five of the fragment ions from each aglycone contain the structural units originally in the C-6 to C-9 regions of the molecules. Structures that are consistent with these correlated findings and with the results of the deuterium labelling experiments are depicted in Scheme 4.

The only other fragments (Structures $\mathbf{d}_{\mathbf{2}} \mathbf{a}$ and $\mathbf{d}_{\mathbf{2}} \mathbf{b}$ ) observed in the experiments on EB appeared at $\mathrm{m} / \mathrm{z} 235$ and 179 in the $\mathrm{MS}^{3}$ spectrum of $\mathrm{m} / \mathrm{z} 309$. These losses match the formulas $\mathrm{C}_{3} \mathrm{H}_{6} \mathrm{O}_{2}$ and $\mathrm{C}_{6} \mathrm{H}_{10} \mathrm{O}_{3}$ and could arise by losses of the C-1-C-2 and C-1-C-4 portions from the $\mathrm{m} / \mathrm{z} 309$ ions as depicted in Scheme 7 .

\section{6-Deoxyerythronolide B (6-dEB)}

Five experiments were performed on a pure sample of 6-dEB. The MS-MS analysis (Figure 4) of the sodiated pseudomolecular ion $(\mathrm{m} / \mathrm{z} 409)$ showed fragment ions at $\mathrm{m} / \mathrm{z} 391,311,293,275,249,237,231,223$, and 191. The MS-MS analysis of deuterated 6-dEB and the MS $^{3}$ spectra of the $\mathrm{m} / \mathrm{z} 391,311,293$, and 275 from 6-dEB and of the corresponding ions from deuterated 6-dEB were also recorded. The results obtained from all of the experiments on 6-dEB are summarized in Tables 3 and 4.

The fragment ions at $m / z$ 391, 311, 293, 275, 249, 237, 231 , and 191 all arise from fragmentations that occur in all of the analogs studied (as discussed above, see Scheme 4). However, in contrast to EB, the $m / z 237$ ion from 6-dEB was observed in the $\mathrm{MS}^{3}$ analysis of $\mathrm{m} / \mathrm{z}$ 311. This loss of $\mathrm{C}_{3} \mathrm{H}_{6} \mathrm{O}_{2}$ is most easily envisaged as originating from the carboxyl terminus of $\mathbf{b}_{\mathbf{1}}$ to give $\mathbf{a}_{\mathbf{1}}$ as depicted in Scheme 4. The MS ${ }^{3}$ analysis of $\mathrm{m} / \mathrm{z} 293$ also shows fragment ions at $\mathrm{m} / \mathrm{z} 223$ and 219 resulting from losses of $\mathrm{C}_{5} \mathrm{H}_{10}$ and $\mathrm{C}_{3} \mathrm{H}_{6} \mathrm{O}_{2}$, respectively. The formula of $\mathrm{m} / \mathrm{z} 223$ is the same as $\mathrm{m} / \mathrm{z} 223$ from $\mathrm{MS}^{3}$ of 407 from EB (Scheme 6). Furthermore, both $\mathrm{m} / \mathrm{z} 223$ fragments show no retained deuterium when the same experiments are run in deuterated media. This strongly suggests that both of these ions have essen-
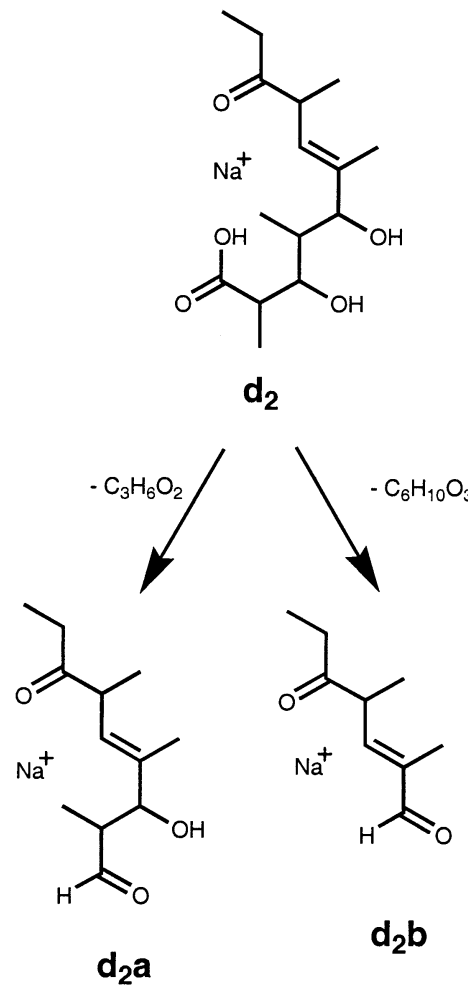

Scheme 7. A representation of the losses of $\mathrm{C}_{3} \mathrm{H}_{6} \mathrm{O}_{2}$ and $\mathrm{C}_{6} \mathrm{H}_{10} \mathrm{O}_{3}$ from $m / z 309\left(\mathbf{d}_{\mathbf{2}}\right)$, isolated from the MS-MS analysis of EB.

tially the same structure (Structure $j$, Schemes 6 and 9) since it is difficult to envisage an alternative structure of this formula, $\mathrm{C}_{10} \mathrm{H}_{16} \mathrm{O}_{4} \mathrm{Na}^{+}$, being produced that contains a different set of oxygen atoms and no deuteriums. This structure and the fact that it is produced by the loss of $\mathrm{C}_{5} \mathrm{H}_{10}$ from $\mathrm{m} / z 293$ suggest that the latter ion has the Structure $\mathbf{d}_{\mathbf{1}} \mathbf{a}_{\mathbf{1}}$ (see Scheme 8). However, the molecular formulas of $\mathrm{m} / \mathrm{z} 209$ and 179 match losses of $\mathrm{C}_{4} \mathrm{H}_{4} \mathrm{O}_{2}$ and $\mathrm{C}_{6} \mathrm{H}_{10} \mathrm{O}_{2}$ from $\mathrm{m} / \mathrm{z}$ 293. Regardless of whether such losses occur directly or stepwise, the most likely origin of these losses is from the C-1-C-3 and C-1-C-4 regions, respectively, of Structure $\mathbf{d}_{\mathbf{1}} \mathbf{b}_{\mathbf{2}}$. Thus, the most likely explanation is

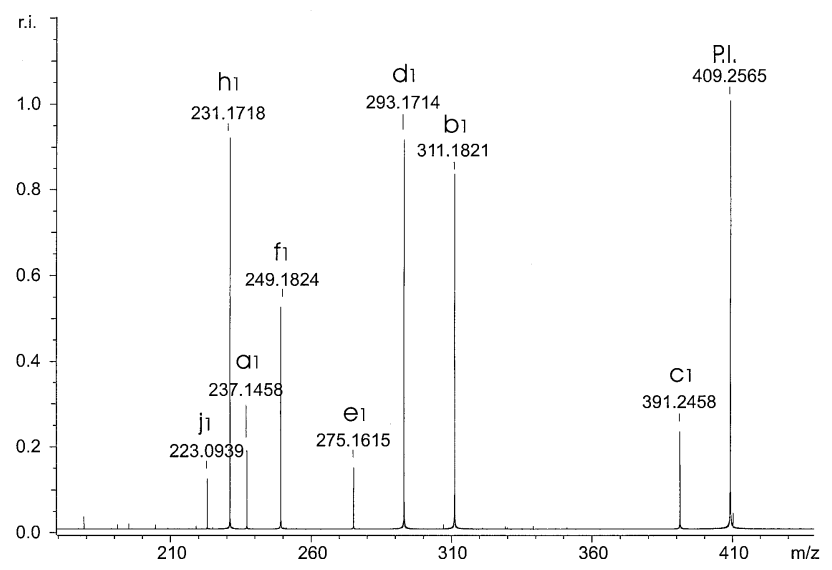

Figure 4. The ESI-FTICR MS-MS product ion spectrum of 6-dEB: precursor ion $\mathrm{m} / \mathrm{z} 409$. 
Table 3. The formula and fragment ion identity for every ion

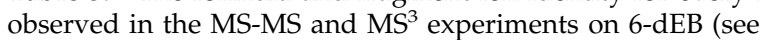
Figure 4)

\begin{tabular}{lccl}
\hline Formula & $\begin{array}{c}\text { Fragment } \\
\text { identity }\end{array}$ & $\begin{array}{c}\text { Number of } \\
\text { deuteriums }\end{array}$ & $\begin{array}{c}\text { Ratio of } \\
\text { deuteriums }\end{array}$ \\
\hline \hline $\mathrm{C}_{21} \mathrm{H}_{38} \mathrm{O}_{6} \mathrm{Na}^{+}$ & P.I. & 3 & \\
$\mathrm{C}_{21} \mathrm{H}_{36} \mathrm{O}_{5} \mathrm{Na}^{+}$ & $\mathrm{C}_{1}$ & $1,2^{\mathrm{b}}$ & $38: 62$ \\
$\mathrm{C}_{15} \mathrm{H}_{28} \mathrm{O}_{5} \mathrm{Na}^{+}$ & $\mathrm{b}_{1}$ & 3 & \\
$\mathrm{C}_{15} \mathrm{H}_{26} \mathrm{O}_{4} \mathrm{Na}^{+}$ & $\mathrm{d}_{1}$ & 1,2 & $40: 60$ \\
$\mathrm{C}_{15} \mathrm{H}_{24} \mathrm{O}_{3} \mathrm{Na}^{+}$ & $\mathrm{e}_{1}$ & $0,1,2$ & $15: 69: 16$ \\
$\mathrm{C}_{14} \mathrm{H}_{26} \mathrm{O}_{2} \mathrm{Na}^{+}$ & $\mathrm{f}_{1}$ & 1,2 & $40: 60$ \\
$\mathrm{C}_{12} \mathrm{H}_{22} \mathrm{O}_{3} \mathrm{Na}^{+}$ & $\mathrm{a}_{1}$ & 1,2 & $12: 88$ \\
$\mathrm{C}_{14} \mathrm{H}_{24} \mathrm{ONa}^{+}$ & $\mathrm{h}_{1}$ & $0,1,2$ & $17: 70: 15$ \\
$\mathrm{C}_{10} \mathrm{H}_{16} \mathrm{O}_{4} \mathrm{Na}^{+}$ & $\mathrm{j}_{1}$ & 0 & \\
$\mathrm{C}_{12} \mathrm{H}_{20} \mathrm{O}_{2} \mathrm{Na}^{+}$ & $\mathrm{d}_{1} \mathrm{a}$ & 1 & \\
$\mathrm{C}_{11} \mathrm{H}_{22} \mathrm{O}_{2} \mathrm{Na}^{+}$ & 209 & & \\
$\mathrm{C}_{9} \mathrm{H}_{16} \mathrm{O}_{3} \mathrm{Na}^{+}$ & 195 & 1 & $15: 71: 15$ \\
$\mathrm{C}_{11} \mathrm{H}_{20} \mathrm{ONa}^{+}$ & $\mathrm{g}_{1}$ & $0,1,2$ & $24: 76$ \\
$\mathrm{C}_{9} \mathrm{H}_{16} \mathrm{O}_{2} \mathrm{Na}^{+}$ & $\mathrm{d}_{2} \mathrm{~b}$ & 0,1 &
\end{tabular}

a For each of the ions observed in the experiments performed using deuterated media, the number of deuteriums present is given.

${ }^{b}$ For species that have different masses only by virtue of the number of deuteriums they contain, the relative intensities are also given.

that isomeric species of $m / z 293$ (Structures $\mathbf{d}_{\mathbf{1}} \mathbf{a}_{\mathbf{1}}, \mathbf{d}_{\mathbf{1}} \mathbf{a}_{\mathbf{2}}$, $\mathbf{d}_{\mathbf{1}} \mathbf{b}_{\mathbf{1}}$, and $\mathbf{d}_{\mathbf{1}} \mathbf{b}_{\mathbf{2}}$ ) are present, each of which gives rise to some of the observed fragments.

The formula of the $m / z 195$ fragment is $\mathrm{C}_{6} \mathrm{H}_{10} \mathrm{O}$ lower than that of $m / z 293$ and could arise from a loss of this formula from any of the isomers of Structure $d_{1}$ (see Scheme 9). These four isomers of $\mathrm{m} / \mathrm{z} 293$ could be produced by the loss of $\mathrm{C}_{6} \mathrm{H}_{10} \mathrm{O}$ from the two isomeric $m / z 391$ fragments, (Structures $\mathbf{c}_{\mathbf{1}} \mathbf{a}$ and $\mathbf{c}_{\mathbf{1}} \mathbf{b}$ ), by the mechanism depicted in Scheme 5. The fragments $c_{1} \mathbf{a}$ and $c_{1} \mathbf{b}$ result from the losses of water from C-5 and $\mathrm{C}-3$ from 6 -dEB. In previous studies, the initial loss of water from erythromycin $\mathrm{A}$ has been proposed to occur from C-9 via a cyclic oxonium ion intermediate [12]. This conclusion was partly based upon the observation that this loss shifted to a loss of $\mathrm{m} / \mathrm{z} 20$ from samples dissolved in deuterated media, owing to the loss of $\mathrm{D}_{2} \mathrm{O}$. In the corresponding experiments run with 6-dEB in the present study, losses of both 19 and 20 occur. Thus this loss of water might mirror that proposed for erythromycin A. Such a loss would result in a cyclic intermediate such as fragment $\mathbf{c}_{\mathbf{1}} \mathbf{c}$, which could, for example, generate fragment $d_{1} a_{1}$ via a retro Diels-Alder reaction. Thus, plausible fragmentation pathways involving the initial loss of water

Table 4. The nominal mass of the fragment ions observed in the various experiments on 6-dEB

\begin{tabular}{ll}
\hline Experiment & \multicolumn{1}{c}{$\begin{array}{c}\text { Observed nominal masses of } \\
\text { significant ions }\end{array}$} \\
\hline \hline MS-MS of $m / z 409$ & $391,311,293,275,249,237,231,223,191$ \\
$M S^{3}$ of $m / z 391$ & $293,275,249,231,223$ \\
$M^{3}$ of $m / z 311$ & $293,275,249,237,231$ \\
$M^{3}$ of $m / z 293$ & $275,249,231,223,219,209,195,179$ \\
$M^{3}$ of $m / z 275$ & 231,191 \\
\hline
\end{tabular}
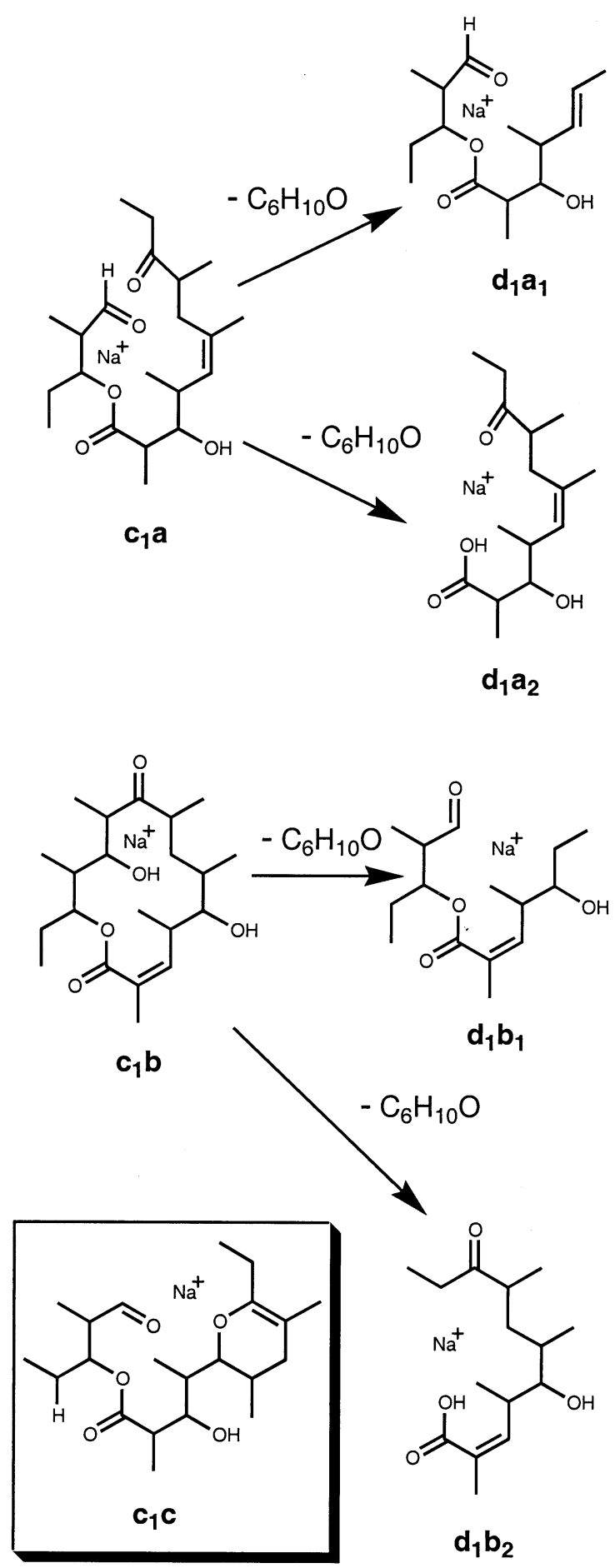

Scheme 8. Possible routes towards four alternative structures of formula $\mathrm{C}_{15} \mathrm{H}_{26} \mathrm{O}_{4} \mathrm{Na}^{+}(\mathrm{m} / z$ 293) from which the subsequent fragmentation routes shown in Scheme 9 could originate.

from any of C-3, C-5, and C-9 can be devised. Some possible illustrative structures for the fragments $\mathrm{m} / \mathrm{z}$ $223,219,209,195$, and 179 and lists of the isomers of $\mathrm{m} / \mathrm{z} 293$ (of those given in Scheme 8) from which they could arise are presented in Scheme 9. In each case, for the sake of clarity, the depicted structure is 


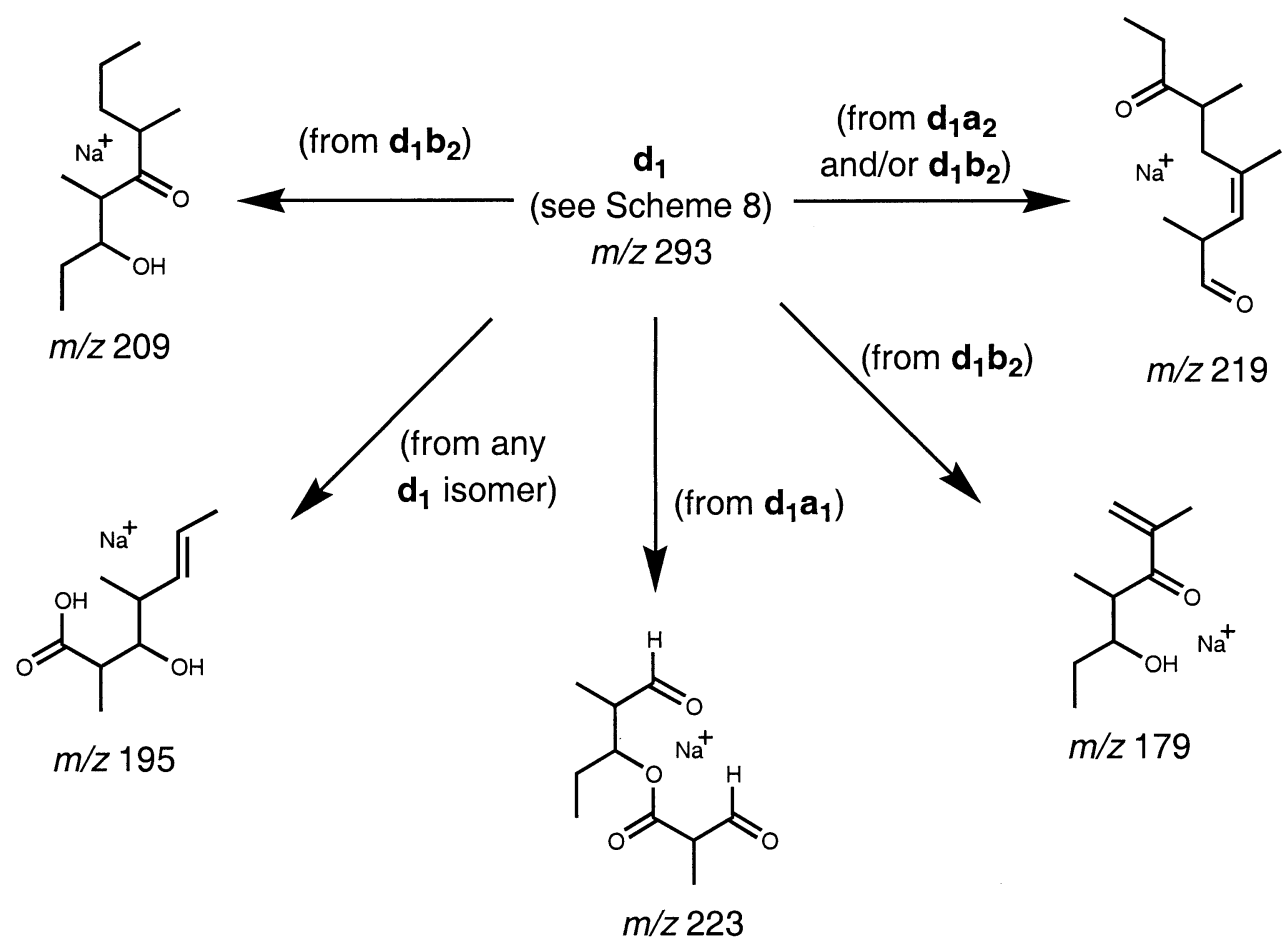

Scheme 9. The observed fragment ions that could most reasonably originate from the 4 possible isomers of fragment $d_{1}$.

arbitrarily chosen as the one that would arise from the first fragment listed on the reaction arrow.

\section{Stutt-6-dEB and Ac-stutt-6-dEB}

The MS-MS analysis of sodiated stutt-6-dEB, $m / z 451$ (Table 5), and Ac-stutt-6-dEB, $m / z 437$ (Table 6), both gave exactly the same fragments ions at $\mathrm{m} / \mathrm{z} 353,291$, 279,273 , and 221. This again illustrates the initial loss of the starter unit, to give ions $\mathrm{m} / \mathrm{z} 353$ of the same formula, which undergo the same subsequent fragmentations. $\mathrm{MS}^{3}$ experiments were performed on two fragments, $m / z 353$ and 335, from stutt-6-dEB. The former spectrum showed five peaks not observed in the latter,

Table 5. The formula, fragment ion identity, and observed mass for every ion observed in the MS-MS and MS ${ }^{3}$ experiments on stutt-6-dEB

\begin{tabular}{lcc}
\hline Formula & $\begin{array}{c}\text { Fragment } \\
\text { identity }\end{array}$ & $\begin{array}{c}\text { Observed } \\
\text { mass }\end{array}$ \\
\hline \hline $\mathrm{C}_{24} \mathrm{H}_{44} \mathrm{O}_{6} \mathrm{Na}^{+}$ & P.I. & 451.30279 \\
$\mathrm{C}_{18} \mathrm{H}_{34} \mathrm{O}_{5} \mathrm{Na}^{+}$ & $\mathrm{b}_{4}$ & 353.23068 \\
$\mathrm{C}_{18} \mathrm{H}_{32} \mathrm{O}_{4} \mathrm{Na}^{+}$ & $\mathrm{d}_{4}$ & 335.21892 \\
$\mathrm{C}_{18} \mathrm{H}_{30} \mathrm{O}_{3} \mathrm{Na}^{+}$ & $\mathrm{e}_{4}$ & 317.20713 \\
$\mathrm{C}_{17} \mathrm{H}_{32} \mathrm{O}_{2} \mathrm{Na}^{+}$ & $\mathrm{f}_{4}$ & 291.22830 \\
$\mathrm{C}_{15} \mathrm{H}_{28} \mathrm{O}_{3} \mathrm{Na}^{+}$ & $\mathrm{a}_{4}$ & 279.19396 \\
$\mathrm{C}_{17} \mathrm{H}_{30} \mathrm{ONa}^{+}$ & $\mathrm{h}_{4}$ & 273.21845 \\
$\mathrm{C}_{14} \mathrm{H}_{26} \mathrm{ONa}^{+}$ & $\mathrm{g}_{4}$ & 233.18753 \\
$\mathrm{C}_{12} \mathrm{H}_{22} \mathrm{O}_{2} \mathrm{Na}^{+}$ & 221 & 221.15118 \\
\hline
\end{tabular}

${ }^{a}$ Mass measurement accuracy is within $3.5 \mathrm{ppm}$ for all ions. $\mathrm{m} / \mathrm{z} 335,291,279,233$, and 221, while the latter spectrum showed peaks at $\mathrm{m} / \mathrm{z} 317$ and 273. The latter spectrum was very weak because of the low concentration of the sample, however, so the absence of the expected $\mathrm{m} / \mathrm{z} 291$ peak was not considered significant. The formulas matching the accurate masses of the ions observed in the experiments on stutt-6-dEB and Ac-stutt-6-dEB are given in Tables 5 and 6 . All of the ions observed in the MS-MS and MS ${ }^{3}$ analyses of these compounds, with the exception of $\mathrm{m} / \mathrm{z} 221$, could be attributed to fragmentation reactions analogous to those observed from all of the other macrolide aglycones (see Scheme 4). The $\mathrm{m} / \mathrm{z}$ 221 fragment $\left(\mathrm{C}_{12} \mathrm{H}_{22} \mathrm{O}_{2} \mathrm{Na}^{+}\right)$could not be correlated to any of the fragments from any of the compounds studied and thus its structure remains unknown.

Table 6. The formula, fragment ion identity, and observed mass for every ion observed in the MS-MS and MS $^{3}$ experiments on Ac-stutt-6-dEB

\begin{tabular}{lcc}
\hline Formula & $\begin{array}{c}\text { Fragment } \\
\text { identity }\end{array}$ & $\begin{array}{c}\text { Observed } \\
\text { mass }\end{array}$ \\
\hline \hline $\mathrm{C}_{23} \mathrm{H}_{42} \mathrm{O}_{6} \mathrm{Na}^{+}$ & P.I. & 437.28693 \\
$\mathrm{C}_{18} \mathrm{H}_{34} \mathrm{O}_{5} \mathrm{Na}^{+}$ & $\mathrm{b}_{6}$ & 353.23074 \\
$\mathrm{C}_{18} \mathrm{H}_{32} \mathrm{O}_{4} \mathrm{Na}^{+}$ & $\mathrm{d}_{6}$ & 335.21929 \\
$\mathrm{C}_{17} \mathrm{H}_{32} \mathrm{O}_{2} \mathrm{Na}^{+}$ & $\mathrm{f}_{6}$ & 291.22811 \\
$\mathrm{C}_{15} \mathrm{H}_{28} \mathrm{O}_{3} \mathrm{Na}^{+}$ & $\mathrm{a}_{6}$ & 279.19370 \\
$\mathrm{C}_{17} \mathrm{H}_{30} \mathrm{ONa}^{+}$ & $\mathrm{h}_{6}$ & 273.21908 \\
$\mathrm{C}_{12} \mathrm{H}_{22} \mathrm{O}_{2} \mathrm{Na}^{+}$ & 221 & 221.15109 \\
\hline
\end{tabular}

${ }^{a}$ Mass measurement accuracy is within $3.0 \mathrm{ppm}$ for all ions. 
Table 7. The formula, fragment ion identity, and observed mass for every ion observed in the MS-MS and MS ${ }^{3}$ experiments on stuttered-EB

\begin{tabular}{|c|c|c|c|c|}
\hline Formula & $\begin{array}{l}\text { Fragment } \\
\text { identity }\end{array}$ & $\begin{array}{l}\text { Observed } \\
\text { mass }^{a}\end{array}$ & $\begin{array}{c}\text { Number of } \\
\text { deuteriums }\end{array}$ & $\begin{array}{c}\text { Ratio of } \\
\text { deuteriums }\end{array}$ \\
\hline $\mathrm{C}_{24} \mathrm{H}_{44} \mathrm{O}_{7} \mathrm{Na}^{+}$ & P.I. & 467.29838 & 4 & \\
\hline $\mathrm{C}_{24} \mathrm{H}_{42} \mathrm{O}_{6} \mathrm{Na}^{+}$ & $\mathrm{C}_{5}$ & 449.28904 & $2,3^{c}$ & $79: 21$ \\
\hline $\mathrm{C}_{24} \mathrm{H}_{40} \mathrm{O}_{5} \mathrm{Na}^{+}$ & $\mathrm{c}_{5}-\mathrm{H}_{2} \mathrm{O}$ & 431.27432 & & \\
\hline $\mathrm{C}_{23} \mathrm{H}_{40} \mathrm{O}_{3} \mathrm{Na}^{+}$ & 387 & 387.28666 & & \\
\hline $\mathrm{C}_{18} \mathrm{H}_{34} \mathrm{O}_{6} \mathrm{Na}^{+}$ & $b_{5}$ & 369.22355 & 4 & \\
\hline $\mathrm{C}_{18} \mathrm{H}_{32} \mathrm{O}_{5} \mathrm{Na}^{+}$ & $d_{5}$ & 351.21460 & 2,3 & $58: 42$ \\
\hline $\mathrm{C}_{18} \mathrm{H}_{30} \mathrm{O}_{4} \mathrm{Na}^{+}$ & $e_{5}$ & 333.20296 & $0,1,2$ & $15: 57: 28$ \\
\hline $\mathrm{C}_{17} \mathrm{H}_{32} \mathrm{O}_{3} \mathrm{Na}^{+}$ & $f_{5}$ & 307.22432 & 2,3 & $58: 42$ \\
\hline $\mathrm{C}_{15} \mathrm{H}_{28} \mathrm{O}_{4} \mathrm{Na}^{+}$ & $a_{5}$ & 295.18779 & 2,3 & $37: 63$ \\
\hline $\mathrm{C}_{17} \mathrm{H}_{30} \mathrm{O}_{2} \mathrm{Na}^{+}$ & $\mathrm{h}_{5}$ & 289.21377 & $0,1,2$ & $15: 57: 28$ \\
\hline $\mathrm{C}_{15} \mathrm{H}_{26} \mathrm{O}_{3} \mathrm{Na}^{+}$ & $\mathrm{a}_{5}-\mathrm{H}_{2} \mathrm{O}$ & 277.17628 & 0,1 & $31: 69$ \\
\hline $\mathrm{C}_{17} \mathrm{H}_{28} \mathrm{ONa}^{+}$ & $\mathrm{h}_{5}-\mathrm{H}_{2} \mathrm{O}$ & 271.20389 & 0,1 & $33: 67$ \\
\hline $\mathrm{C}_{14} \mathrm{H}_{26} \mathrm{O}_{2} \mathrm{Na}^{+}$ & $g_{5}$ & 249.18255 & 1,2 & $51: 49$ \\
\hline $\mathrm{C}_{12} \mathrm{H}_{22} \mathrm{O}_{3} \mathrm{Na}^{+}$ & 237 & 237.14591 & 1,2 & $38: 62$ \\
\hline $\mathrm{C}_{14} \mathrm{H}_{24} \mathrm{ONa}^{+}$ & $\mathrm{g}_{5}-\mathrm{H}_{2} \mathrm{O}$ & 231.17134 & 0,1 & $35: 65$ \\
\hline $\mathrm{C}_{10} \mathrm{H}_{16} \mathrm{O}_{4} \mathrm{Na}^{+}$ & $\mathrm{j}_{5}$ & 223.09382 & 0 & \\
\hline $\mathrm{C}_{12} \mathrm{H}_{20} \mathrm{O}_{2} \mathrm{Na}^{+}$ & 219 & 219.13592 & $0,1,2$ & $23: 48: 29$ \\
\hline $\mathrm{C}_{11} \mathrm{H}_{20} \mathrm{O}_{2} \mathrm{Na}^{+}$ & $g_{5}$ & 207.13623 & 0,1 & $32: 68$ \\
\hline $\mathrm{C}_{6} \mathrm{H}_{12} \mathrm{ONa}^{+}$ & 123 & 123.07781 & 1 & \\
\hline
\end{tabular}

aMass measurement accuracy is within $6.0 \mathrm{ppm}$ for all ions.

${ }^{b}$ For each of the ions observed in the experiments performed using deuterated media, the number of deuteriums present is given.

${ }^{\mathrm{c}}$ For species that have different masses only by virtue of the number of deuteriums they contain, the relative intensities are also given.

\section{Stutt EB}

The results of the MS-MS and MS ${ }^{3}$ experiments performed with stutt-EB in non-deuterated and deuterated media are presented in Tables 7 and 8 . The fragment ions $\mathrm{m} / \mathrm{z} 449,369,351,333,307,295,289$, and 249 can be attributed to analogous fragmentations to those observed for all of the other compounds (see Scheme 4). All of these fragment ions match molecular formulas $\mathrm{C}_{3} \mathrm{H}_{6}$ higher than the corresponding ions from EB, reflecting the retention of the "stuttered" unit. The $\mathrm{m} / \mathrm{z}$ 223 fragment matches the same formula as those ions of this mass observed from the MS-MS analyses of EB and 6-dEB and, similarly, does not retain any deuteriums during fragmentation from the deuterated pseudomolecular ion. Therefore, this fragment ion probably has the Structure j. The ions at $\mathrm{m} / \mathrm{z} 431$ and 387 probably arise by sequential losses of $\mathrm{H}_{2} \mathrm{O}$ and $\mathrm{CO}_{2}$ from $\mathrm{m} / z 449$. The $\mathrm{MS}^{3}$ spectrum of $\mathrm{m} / \mathrm{z} 307$ shows a single fragment ion, $m / z 237$, with a formula matching to a loss of $\mathrm{C}_{5} \mathrm{H}_{10}$. This loss can be attributed to fragmentation that is

Table 8. The nominal mass of the fragment ions observed in the various experiments on stutt-EB

\begin{tabular}{ll}
\hline Experiment & \multicolumn{1}{c}{$\begin{array}{c}\text { Observed nominal masses of } \\
\text { significant ions }\end{array}$} \\
\hline \hline MS-MS of $m / z$ 467 & $449,369,351,307,295,289,277,249$, \\
& 231,123 \\
$M S^{3}$ of $m / z$ 449 & $431,387,351,333,289,223$ \\
$\mathrm{MS}^{3}$ of $\mathrm{m} / \mathrm{z}$ 369 & $351,333,307,295,289,277,271,237$, \\
& $231,207,123$ \\
$\mathrm{MS}^{3}$ of $\mathrm{m} / \mathrm{z}$ 351 & $333,307,289,277,249,231,207$ \\
$\mathrm{MS}^{3}$ of $\mathrm{m} / \mathrm{z}$ 307 & 237 \\
\hline
\end{tabular}

analogous to the postulated formation of $\mathrm{m} / \mathrm{z} 179$ from $\mathrm{m} / \mathrm{z} 249$ from 6-dEB, shown in Scheme 9. The $\mathrm{m} / \mathrm{z} 231$, 271 , and 219 fragments could result from loss of $\mathrm{H}_{2} \mathrm{O}$ from $\mathrm{m} / \mathrm{z} 249,289$, and 237 respectively. It is not possible to identify the origin of the $\mathrm{m} / \mathrm{z} 207$ peak from the data obtained. However, this fragment retains one deuterium atom from the deuterated pseudomolecular ion and has a molecular formula $\mathrm{C}_{6} \mathrm{H}_{10}$ less than fragment $h_{5}$ (see Scheme 4). Therefore, it is possible that it arises by the loss of the C-2-C-5 portion of fragment $\mathbf{h}_{5}$. The remaining fragment, $\mathrm{m} / \mathrm{z} 123$, has the formula $\mathrm{C}_{6} \mathrm{H}_{12} \mathrm{ONa}^{+}$, and could be generated by a plethora of routes, so will not be considered further.

\section{Conclusion}

The fragmentation analysis of six macrolide aglycones with differing ring sizes, starter units, presence or absence of the C-6 hydroxyl, and a high degree of symmetry was presented. The amount of structural information that could be gleaned from such an analysis was limited; for example, some ions could not be induced to fragment to produce $\mathrm{MS}^{3}$ spectra. There were also ambiguities; for example, in several cases we interpreted that alternative isomeric structures for various fragments were produced, thus complicating the analysis. However, the accuracy with which the mass of each of the ions was measured allowed each to be attributed to a single formula, which allowed us to rule out a multitude of alternative fragmentation pathways. The availability of the macrolide aglycone analogs in high purity enabled corresponding experiments to be performed on each. Thus, correlations could be de- 
duced between the fragmentation pathways of the analogs, which displayed a striking degree of homology (Scheme 4). In particular, the initial loss of a fragment containing the starter unit from each of the pseudomolecular ions suggests the potential use of this fragmentation as a diagnostic tool. However, it appeared that the dehydrated pseudomolecular ion from 6-dEB lost two fragments of the same formula, $\mathrm{C}_{6} \mathrm{H}_{10} \mathrm{O}$, as the starter unit-containing fragment, from separate regions of the ion. This demonstrates that the data obtained from such fragmentation experiments is potentially confusing and that care should be taken in the diagnostic use of the starter unit-containing loss for the identification of biosynthetically related macrolide aglycone metabolites.

The high degree of similarity between the various fragmentation pathways could be used to predict the structure of a new octaketide analog as stutt-EB from a small sample $(\sim 200 \mu \mathrm{g}$, purity $\sim 90 \%)$ of this compound. Subsequent scale-up of the bacterial fermentations, followed by isolation and full NMR characterization confirmed this prediction. Further $\mathrm{MS}^{3}$ experiments with the pure compound then revealed more similarities between the fragmentation pathways followed by this and the other compounds presented. Taken together, the results presented here demonstrate the utility of high-resolution accurate-mass CID sequential MS analysis in the preliminary screening of bacterial fermentations for new macrolide aglycone analogs.

\section{Acknowledgments}

The authors gratefully thank Dr. Barrie Wilkinson of GlaxoSmithKline for the gift of stutt-6-dEB and Ac-stutt-6-dEB. They acknowledge GlaxoSmithKline, the Wenner-Gren Center Foundation, Unilever Safety and Environmental Assurance Centre, and the Biotechnology and Biological Sciences Research Council for financial support.

\section{References}

1. Staunton, J.; Wilkinson, B. Biosynthesis of Erythromycin and Rapamycin. Chem. Rev. 1997, 97, 2611.

2. Carreras, C. W.; Pieper, R.; Khosla, C. The Chemistry and Biology of Fatty Acid, Polyketide, and Non-Ribosomal Peptide Biosynthesis. Top. Curr. Chem. 1997, 188, 85.

3. Khosla, C. Harnessing the Biosynthetic Potential of Modular Polyketide Synthases. Chem. Rev. 1997, 97, 2577.

4. Staunton, J.; Wilkinson, B. The Biosynthesis of Aliphatic Polyketides. Top. Curr. Chem. 1998, 195, 49.

5. McDaniel, R.; Thamchaipenet, A.; Gustafsson, C.; Fu, H.; Betlach, M.; Ashley, G. Multiple Genetic Modifications of the
Erythromycin Polyketide Synthase to Produce a Library of Novel "Unnatural" Natural Products. Proc. Natl. Acad. Sci. U.S.A. 1999, 96, 1846.

6. Khosla, C. Combinational Biosynthesis: New Tools for the Medicinal Chemist. Chemtracts Org. Chem. 1998, 11, 1.

7. Leadlay, P. F. Combinatorial Approaches to Polyketide Biosynthesis. Curr. Opin. Chem. Biol. 1997, 1, 162.

8. (a) Shomo, R. E.; Marshall, A. G.; Lattimer, R. P. Laser Desorption Fourier-Transform Ion-Cyclotron Resonance versus Field Desorption Magnetic-Sector Mass SpectrometryErythromycin, Amoxicillin, Digoxin, and Daunorubicin. Int. J. Mass Spectrom. Ion Processes 1986, 72, 209. (b) Pleasance, S.; Kelly, J.; Leblanc, M. D.; Quilliam, M. A.; Boyd, R. K.; Kitts, D. O.; McErlane, K.; Bailey, M. R.; North, D. H. Determination of Erythromycin A in Salmon Tissue by Liquid-Chromatography with Ionspray Mass Spectrometry. Biol. Mass Spectrom 1992, 21, 675. (c) Shida, Y.; Deterding, L. J.; O'Hara, K.; Kono, M.; Tomer, K. B. Macrolide Antibiotics-Structure Determination by Fast-Atom-Bombardment Tandem Mass Spectrometry. Tetrahedron 1993, 49, 9221. (d) Delepine, D.; Hurtaud-Pessel, D.; Sanders, P. Multiresidue Method for Confirmation of Macrolide Antibiotics in Bovine Muscle by Liquid-Chromatography Mass Spectrometry. J. AOAC Int 1996, 79, 397. (e) Volmer, D. A.; Hui, J. P. M. Study of Erythromycin A Decomposition Products in Aqueous Solution by Solid-Phase Micro-Extraction Liquid-Chromatography Tandem Mass Spectrometry. Rapid Commun. Mass Spectrom. 1998, 123, 12.

9. Weissman, K. J.; Bycroft, M.; Cutter, A. L.; Hanefeld, U.; Frost, E. J.; Timoney, M. C.; Harris, R.; Handa, S.; Roddis, M.; Staunton, J.; Leadlay, P. F. Evaluating Precursor-Directed Biosynthesis Towards Novel Erythromycins Through in Vitro Studies on a Bimodular Polyketide Synthase. Chem. Biol. 1998, 5, 743 .

10. Dutton, C. J.; Hooper, A. M.; Leadlay, P. F.; Staunton, J. Avermectin Biosynthesis-Intact Incorporation of a Diketide Chain-Assembly Intermediate into the Polyketide Macrolide Ring. Tet. Lett. 1994, 35, 327.

11. Gates, P. J.; Kearney, G. C.; Jones, R.; Leadlay, P. F.; Staunton, J. Structural Elucidation Studies of Erythromycins by Electrospray Tandem Mass Spectrometry. Rapid Commun. Mass Spectrom. 1999, 13, 242.

12. Kearney, G. C.; Gates, P. J.; Leadlay, P. F.; Staunton, J.; Jones, R. Structural Elucidation Studies of Erythromycins by Electrospray Tandem Mass Spectrometry II. Rapid Commun. Mass Spectrom. 1999, 13, 1650.

13. Wilkinson, B.; Foster, G.; Rudd, B. A. M.; Taylor, N. L.; Blackaby, A. P.; Sidebottom, P. J.; Cooper, D. J.; Dawson, M. J.; Buss, A. D.; Gaisser, S.; Böhm, I. U.; Rowe, C. J.; Cortés, J.; Leadlay, P. F.; Staunton, J. Novel Octaketide Macrolides Related to 6-Deoxyerythronolide B Provide Evidence for Iterative Operation of Erythromycin Polyketide Synthase. Chem. Biol. 2000, 7, 111.

14. Heck, A. J. R.; DeKoning, L. J.; Pinkse, F. A.; Nibbering, N. M. M. Mass-Specific Selection of Ions for Fourier-Transform Ion-Cyclotron Resonance Mass SpectrometryUnintentional Off-Resonance Cyclotron Excitation of Selected Ions. Rapid Commun. Mass Spectrom. 1991, 5, 406. 